Brit. J. vener. Dis. (1960), 36, 270.

\title{
BILHARZIA IN A PATIENT WITH GONORRHOEA*
}

\author{
BY \\ R. M. WARREN \\ Special Treatment Centre, Southampton
}

Bilharzia is sufficiently rare in Britain to make the following case worthy of being recorded.

\section{Case Report}

A married Iraqi sailor, aged 22 years, was seen on September 14, 1959, with acute gonorrhoea. He had developed urethritis on September 9, some 5 days after exposure with a prostitute in Southampton. His symptoms disappeared after treatment with 300,000 units PAM and $1 \mathrm{~g}$. streptomycin; on September 16 there was no discharge and the urine was clear except for a very few shreds in the first glass. However, on September 21, although discharge was absent, a twoglass test showed that the urine in the first glass was hazy and contained a few small blood clots. Sulphathiazole, $5 \mathrm{~g}$. daily, was given for 5 days.

The patient did not report again until October 15, when the urine was hazy and contained blood clots. On rectal examination, the right lobe of the prostate and the right vesicle were thought to be enlarged and tender. $1 \mathrm{~g}$. streptomycin and 600,000 units PAM were given daily for 5 days. The urine was found to be alkaline and contained a moderate cloud of albumen. The deposit showed large numbers of red blood cells and a moderate number of pus cells. No casts were seen. There was a scanty growth of Proteus vulgaris, but $N$. gonorrhoeae was not isolated. Treatment with Urolucosil and aureomycin had no effect, but subsequent prostatic examination did not reveal any tenderness of the prostate or vesicles.

On November 5, a specimen of urine was sent to the laboratory. Examination for tubercle and the ova of bilharzia was requested in addition to routine investigations. A first morning specimen was sent on the following day with a similar request. In addition an appointment was made with the genito-urinary surgeon for cystoscopy. Both urine specimens were negative for tuberculosis and bilharzia and the cell content remained as before.

At cystoscopy on November 16, dark red granular patches were noted on the bladder wall, and small yellowish grey glistening nodules were seen apparently just beneath the surface of the bladder mucosa. Some of the nodules were bleeding. They were situated about

* Received for publication November 27, 1959.
$2 \mathrm{in}$. above the right ureteric orifice. The opinion was still that the diagnosis should be either tuberculosis or bilharzia. Urine from the bladder showed a few red and white cells and casts, and scanty Schistosoma haematobium. A miracidium is shown free (Fig. 1) and encased (Fig. 2), and Fig. 3 shows an empty case after the miracidium had left it.

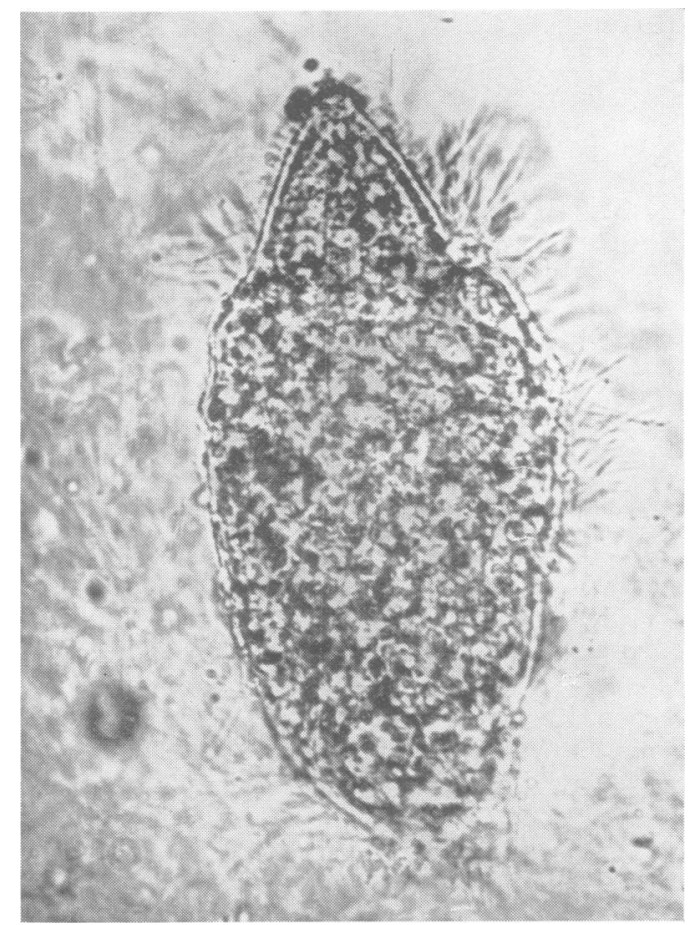

FIG. 1.-A free miracidium.

Treatment with Stibophen was started. $1.5 \mathrm{ml}$. was given on November $23,3.5 \mathrm{ml}$. the following day, and $5 \mathrm{ml}$. thereafter daily for 24 days, a total of $125 \mathrm{ml}$. Ova of Schistosoma haematobium were seen in the mid-stream urine on December 2, but none on December 12 , or ever subsequently. 


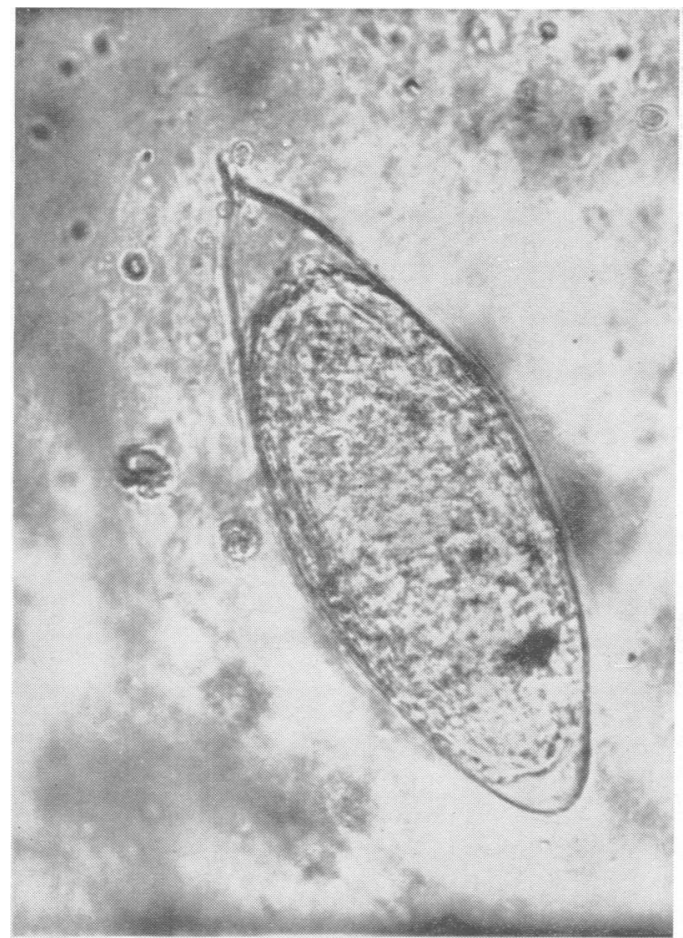

FIG. 2.-An encased miracidium.

Cystoscopy was again performed on December 21, when the patches noted before were still present but the nodules were mainly absent. A red raised area and two other small areas lateral to this and similar in appearance were noted, and two nodules were seen just above the right ureteric orifice. The opinion "lesion still probably active" was given. A catheter specimen of urine showed no ova of Schistosoma haematobium. Stibophen treatment was stopped on January 9, and 2 days later, after four negative urine examinations for the ova of Schistosoma haematobium, cystcscopy showed a small injected area at the site of the previously-noted bilharzia and two small nodules. The rest of the bladder was clear. A catheter specimen of urine showed a few red blood cells and casts but no ova of Schistosoma haematobium.

At a further cystoscopy on March 29, the bladder was practically clear. A catheter specimen of urine showed scanty red blood cells and leucocytes and numerous urinary tract epithelial cells. No ova of Schistosoma haematobium were seen.

\section{Discussion}

This case of bilharzia was felt to be worthy of recording because it was associated with an acute gonococcal infection and the clinical picture was originally thought to be suggestive of a vesiculitis.

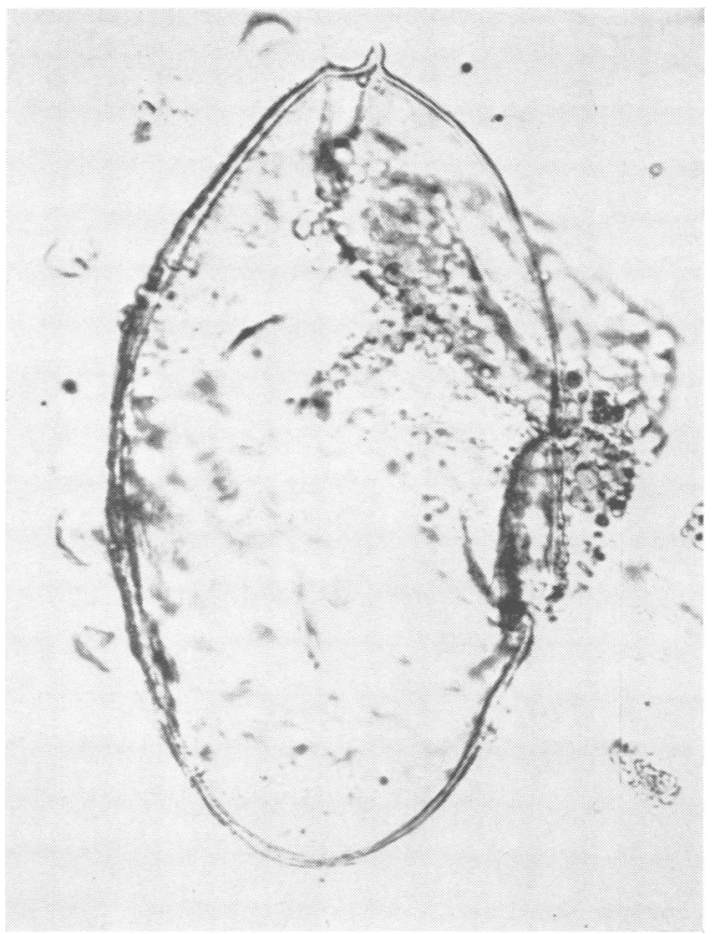

FIG. 3.-Empty case.

However, casting the diagnostic net widely resulted in the catching of a most unusual fish. It is interesting to note that the diagnosis was not confirmed until after examination of the urine taken during cystoscopic examination. Although ova were seen in the mid-stream urine subsequently, they were not observed initially.

Although commonplace in other parts of the world, particularly in the Near East, bilharzia is an unusual complaint in Southampton, in spite of the influx of ships from all parts of the world, the latest case having been recorded 25 years ago. Treatment with Stibophen appeared to be effective and free from unpleasant side-effects. The end-results of bilharzia may be very unpleasant and it is thought to be a pre-cancerous condition. The period of follow-up was only 4 months and this may not be adequate. The patient was instructed to obtain further medical advice on his return home.

My grateful thanks are due to Mr. S. M. Lytle, genito-urinary surgeon at the Southampton General Hospital, for carrying out the cystoscopic examinations; to Dr. Dobson for his routine reports on the urine; to Dr. H. T. Findlay of the Public Health Laboratory Service for his good offices in obtaining the advice of 
Brigadier Boyd regarding treatment of the bilharzia infection; and, finally, to Mr. A. R. Hockley, B.Sc., of the Zoology Department of the University of Southampton, who very kindly took the photo-micrographs.

\section{Summary}

Soon after the successful treatment of his gonorrhoea, an Iraqi sailor developed pyuria with small blood clots. Appearances on cystoscopy suggested tuberculosis or bilharzia and Schistosoma haematobium were found in the urine collected from the bladder. There was a satisfactory response to treatment with Stibophen.

\section{Bilharziose chez un homme atteint de blennorragie}

\section{Résumé}

Peu de temps après un traitement efficace de sa blennorragie, un marin irakien nota du pus et de petits caillots sanguins dans son urine. L'image cystoscopique fit penser à la tuberculose ou la bilharziose et l'identification du Schistosoma haematobium dans l'urine recueillie au cours de la cystoscopie décida le diagnostic. Le traitement au Stibophen donna un résultat satisfaisant.

\section{BOOK REVIEWS}

D ifferential Diagnosis of Yaws. By C. J. Hackett and L. J. A. Loewenthal. 1960. World Health Organization, Geneva, Monograph Series No. 45, pp. 88, 52 figs. Available from H.M. Stationery Office, P.O. Box 569, London, S.E.1. (17s. 6d.; $\$ 3 \cdot 25$; Swiss frs. 10).

The clinical diagnosis of yaws may be easy or difficult. Its differentiation from other skin conditions may sometimes tax the acumen of even the experienced dermatologist practising in areas where this treponematosis is endemic. The mass campaigns against yaws, made possible by the availability of penicillin and organized by national public health services aided by W.H.O., must depend largely on non-medical personnel who have been given special instruction about the recognition, treatment, and control of yaws. Many of these eradication campaigns have now reached their later stages of resurvey when the florid manifestations of yaws have become uncommon. In these circumstances, many lesions not due to yaws and not influenced by penicillin assume increased significance, and accuracy in differential diagnosis becomes very important in assessing the success of the campaign and in planning its further activities. This monograph, which has been prepared to help field workers, is a companion volume to An International Nomenclature of Yaws Lesions (W.H.O. Monograph Series No. 36; reviewed in this Journal (1958), 34, 112). The fifty-two blackand-white clinical photographs of non-treponemal conditions provide the basis of the present volume; their quality is high and only a short text is required. Lesions occurring on the soles of the feet, especially in those working bare-foot in the wet season in tropical areas, may readily be confused with the hyperkeratotic lesions of yaws and this problem receives special attention. The monograph will not only serve its special purpose admirably but should also interest those, particularly dermatologists, practising in the tropics.

S.M.L.

Atlas and Manual of Dermatology and Venereology. By W. Burckhardt, trans. S. Epstein. 1959. Pp. 276, 99 col. pl. and 73 figs. Baillière, Tindall and Cox, London. (£5 12s.).

This book is intended for the use of medical students, general practitioners, and non-dermatological specialists. The 99 coloured illustrations are reproduced from excellent colour photographs. This concise Atlas will be useful for quick reference and revision; for essential further reading, a list of major references is included. Dr. Peter A. J. Smith, Dermatology Department, The London Hospital, has advised on the text with particular reference to therapy used in Great Britain.

The section on venereal diseases contains many excellent illustrations in colour and in general the short text is probably adequate for the limited purpose of the book. Most British venereologists will feel that twenty injections of bismuth preparatory to penicillin in neurosyphilis involves undue delay. Non-gonococcal urethritis is dealt with perfunctorily and the rarity of Reiter's syndrome is overemphasized. Amongst the treatments recommended for non-gonococcal urethritis, penicillin is unlikely to be of benefit.
A.C.C.D. 